\title{
Middle Ear Polyp
}

National Cancer Institute

\section{Source}

National Cancer Institute. Middle Ear Polyp. NCI Thesaurus. Code C6933.

A benign polypoid growth in the middle ear. 